\title{
PERFORMANCE OF TREATED SEEDS OF DIFFERENT SOYBEAN CULTIVARS IN FUNCTION OF ENVIRONMENTS AND STORAGE PERIODS
}

Denilson Paulo da Rosa Mavaieie ${ }^{1}$, Everson Reis Carvalho ${ }^{1}$, Valquíria de Fátima Ferreira ${ }^{2}$, João Almir Oliveira ${ }^{1}$, Thaís Francielle Ferreira ${ }^{1}$, Leandro Vilela Reis ${ }^{1}$

${ }^{1}$ Federal University of Lavras - Minas Gerais, Brazil. E-mail: dmavaieie@gmail.com, eversoncarvalho@ufla.br, jalmir@dag.ufla.br, franthata@yahoo.com.br, leandroreis833@gmail.com

${ }^{2}$ Syngenta Seeds Ltda. E-mail: ffval@yahoo.com.br

\section{ABSTRACT}

The objective of this study was to evaluate the performance of seeds of different soybean cultivars treated in function of environments and storage periods, at Alto Garças, State of Mato Grosso, Brazil. The experimental design was completely randomized in $2 \times 5 \times 6$ factorial design (controlled temperature and $\mathrm{RH}$ conditions, $10{ }^{\circ} \mathrm{C}$ with $50 \% \mathrm{RH}$ and at room temperature) five storage periods: $0,2,4,6$, and 8 months; seeds from six soybean cultivars (TMG 1176, TMG 1179, TMG 115, TMG 132, TMG 133, and GB 874) were used for the following determinations: germination, accelerated aging, electrical conductivity, cold test, and seedling emergence. Seeds of soybean cultivars treated with insecticide (Imidacloprid + Thiodicarb) and fungicide (Carboxin + Thiram) stored under controlled temperature and relative humidity conditions maintain the physiological quality for eight months of storage. At room temperature conditions storaged at Alto Garças, MT, the deterioration rate of seeds treated with insecticide (Imidacloprid + Thiodicarb) and fungicide (Carboxin + Thiram) is accentuated after six months of storage.

Keywords: Glycine max, seed quality, seed treatment

\section{DESEMPENHO DE SEMENTES TRATADAS DE DIFERENTES CULTIVARES DE SOJA EM FUNÇÃO DE AMBIENTES E PERÍODOS DE ARMAZENAMENTO}

\section{RESUMO}

O objetivo deste trabalho foi avaliar o desempenho de sementes de diferentes cultivares de soja tratadas em função de ambientes e períodos de armazenamento, em Alto Garças, MT. O delineamento experimental foi inteiramente casualizado no fatorial $2 \times 5 \times 6$ (temperatura controlada e condições de UR, $10^{\circ} \mathrm{C}$ com $50 \%$ de UR e à temperatura ambiente) cinco períodos de armazenamento: 0, 2, 4, 6 e 8 meses; sementes de seis cultivares de soja (TMG 1176, TMG 1179, 
TMG 115, TMG 132, TMG 133 e GB 874) foram utilizadas as seguintes determinações: germinação, envelhecimento acelerado, condutividade elétrica, teste a frio e emergência de plântulas. Sementes de cultivares de soja tratadas com inseticida (Imidacloprido + Tiodicarbe) e fungicida (Carboxin + Thiram) armazenadas em condições de temperatura e umidade relativa controladas mantém a qualidade fisiológica até oito meses de armazenamento. Em condições de temperatura ambiente em armazém, em Alto Garças, MT, a velocidade de deterioração de sementes tratadas com inseticida (Imidacloprido + Tiodicarbe) e fungicida (Carboxin + Thiram) é acentuada a partir de seis meses de armazenamento.

Palavras-chave: Glycine max, qualidade de semente, tratamento de sementes

\section{INTRODUCTION}

The soybean crop is among the most important in Brazilian agricultural scenario and the country is currently the second largest producer and exporter of soybeans worldwide. In recent years, soybean crop has become a significant source of foreign currency for the country, which produced 115.030 million tons in 2018/19 harvest, occupying an area of 35.874 million hectares with an average yield of 3, $206 \mathrm{~kg} \mathrm{ha}^{-1}$ (CONAB, 2019).

The successful production of soybean seeds and all steps in obtaining a crop with adequate population of plants requires the correct use of several cultural practices and adequate conditions for the use of good quality seeds (CUNHA et al., 2015).

Soybean seeds, due to the nature of their chemical composition, already show a low potential for storage. Additionally, there is a great variation in the behavior among diferent cultivars launched every year in order to serve the market with materials more resistant to certain diseases and adapted to different regions. Therefore, the quality of soybean seeds can be maintained under controlled temperature and relative humidity conditions for long storage periods (DEMITO \& AFONSO, 2009).

Among the practices used in seed production, is the chemical treatment of seeds, which, for technical and logistical reasons can be performed before storage (BRZEZINSKI et al., 2015). This process consists of applying compounds capable of protecting and controlling diseases in the initial period of crop establishment (BALARDIN et al., 2011). 
On the other hand, despite the use of various practices and technologies, there is still postharvest damage throughout storage, as seeds are exposed to external factors such as temperature and relative humidity (REGINATO, 2014).

Soybean seed quality may be influenced by storage genotype and storage conditions with a relative humidity of $80 \%$ affecting the physiological quality of soybean cultivars in the warehouse (SCHONS et al., 2018).

Carvalho et al. (2014) reported that during storage in the cold and dry chamber, there was no change in seed quality and that soybean genotypes presented different levels of storage tolerance different isoenzymatic expressions.

Temperature and relative humidity (RH) at storage influence significantly on seed deterioration, which can be minimized under suitable conditions of these factors (TOLEDO et al., 2009). Storage conditions directly influence seed quality since it helps to maintain the batch characteristics. In addition, soybean seeds stored at air-conditioned environment show higher ability to keep physiological quality compared to those stored in an environment without refrigeration (ZUCHI et al., 2013; JUVINO et al., 2014; SMANIOTTO et al., 2014).

Biotechnology and plant genetics associated with seed treatment technology allows high productivity for producers and market demand (FERREIRA et al., 2016). Currently, seed companies are adopting alternatives, such as the anticipated seed chemical treatment process before bagging and storage. In this context, the aim of this study was to evaluate the performance of treated seeds of different soybean cultivars in function of environments and storage periods, at Alto Garças, MT, State of Mato Grosso, Brazil.

\section{MATERIAL AND METHODS}

The experiment was carried out at the Central Seed Laboratory of the Federal University of Lavras (UFLA), Lavras -MG, for storage in cold and dry chamber $\left(10^{\circ} \mathrm{C}\right.$ and $\left.50 \% \mathrm{RH}\right)$ and at the conventional warehouse of the company Sementes Arco Íris at Alto Garças, MT, Brazil, for storage of seeds under uncontrolled conditions. Seeds were stored in these conditions between June and March 2014/15, obtaining temperature of $22{ }^{\circ} \mathrm{C}$ and $73 \% \mathrm{RH}$ on average. Seeds were produced under similar edaphoclimatic conditions at the farm of the company Sementes Arco Íris at Alto

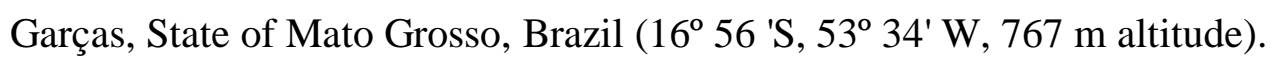


The experimental design was completely randomized in 2 x 5 x 6 factorial design (controlled temperature and $\mathrm{RH}$ conditions, $10^{\circ} \mathrm{C}$ with $50 \% \mathrm{RH}$ and at room temperature in a warehouse in Sementes Arco Iris at Alto Garças, State of Mato Grosso, Brazil; five storage periods: 0, 2, 4, 6, and 8 months; Seeds from six soybean cultivars (TMG 1176, TMG 1179, TMG 115, TMG 132, TMG 133, and GB 874). Seeds from six soybean cultivars were used, all with RR (Roundup Ready) technology. Seeds were treated with $\operatorname{CropStar}{ }^{\circledR}$ insecticide (imidacloprid + thiodicarb) at the dosage of $500 \mathrm{~mL} 100 \mathrm{~kg}^{-1}$ of seed and with the fungicide Vitavax Thiram ${ }^{\circledR}$ (carboxin + thiram) in the dosage $250 \mathrm{~mL} 100 \mathrm{~kg}^{-1}$ of seeds plus water in the ratio $250 \mathrm{~mL} 100 \mathrm{~kg}^{-1}$ of seed. The treated seeds were packed in corrugated fiberboard and stored for eight months under two environments as described above.

The physiological quality of seeds was evaluated every two months during eight months. Four subsamples of 50 seeds were used for the following determinations: germination, accelerated aging, electrical conductivity, cold test, and seedling emergence.

For the germination test, subsamples were sown in germitest paper (three sheets) moistened with distilled water in an amount equivalent to 2.5 times the dry paper weight. The assembled rolls were kept in germinator at $25^{\circ} \mathrm{C}$ for five days, when the evaluation was performed. Results were expressed as percentage of normal seedlings (BRASIL, 2009).

In order to evaluate the accelerated aging, subsamples were conditioned on a metallic mesh in gerbox plastic boxes with $40 \mathrm{~mL}$ of distilled water in the bottom. These gerboxes were incubated at $42{ }^{\circ} \mathrm{C}$ for $48 \mathrm{~h}$ in a BOD chamber (MARCOS FILHO, 1999). Then, the germination test was performed, with evaluation of normal seedlings five days after sowing. Results were expressed as percentage of normal seedlings for each treatment.

The electrical conductivity was measured in subsamples, which were weighed, placed in a plastic glass with $75 \mathrm{ml}$ of deionized water and kept at $25^{\circ} \mathrm{C}$ at BOD chamber. After $24 \mathrm{~h}$ of soaking, the electrical conductivity was read in a Digimed CD-21 electrical conductivity meter and results were expressed in $\mu \mathrm{S} . \mathrm{cm}^{-1}$. $\mathrm{g}^{-1}$ according to the methodology described by Vieira (1994).

In the cold test, subsamples were sown in a plastic tray containing 2:1 sand and soil substrate. Substrate moisture was adjusted to $60 \%$ water-holding capacity. After sowing, trays were kept in a cold chamber at $10{ }^{\circ} \mathrm{C}$ and $50 \% \mathrm{RH}$ for five days and then transferred to a plant growth chamber at $25^{\circ} \mathrm{C}$ under photoperiod of $12 \mathrm{~h}$. After seven days under these conditions, the number of normal seedlings emerged was evaluated. 
To determine seedling emergence, sowing of seed subsamples was performed in plastic trays containing 2:1 sand and soil substrate moistened at $60 \%$ water-holding capacity. After sowing, the trayes were kept in a plant growth chamber at $25{ }^{\circ} \mathrm{C}$ alternating dark and light cycles (12 h). The percentage of normal seedlings at 14 days was considered.

Statistical analysis of data was performed using Sisvar® software (FERREIRA, 2014) by the $\mathrm{F}$ test, $\mathrm{p}<0.05$. When pertinent, the mean values were compared using the Scott-Knott test at a probability of $5 \%$, for qualitative data. For the quantitative data, when the significance effect was verified, the polynomial regression was performed.

\section{RESULTS AND DISCUSSION}

The results of the analysis of variance (Table 1) obtained in the treated seeds from the different soybean cultivars showed a triple interaction between cultivar, storage environment and storage period for the following variables: accelerated aging (AA), electrical conductivity (EC), cold test (CT), and emergence percentage (\%E). For germination $(\% \mathrm{G})$ there was double interaction between cultivar and storage period, storage environment and storage period, and cultivar and storage environment.

Tabela1: Analysis of variance of results evaluation: Germination (\%G), accelerated aging (AA), emergence percentage (\%EM), electrical conductivity (EC) e cold test (CT), from different soybean cultivars stored according to five storage periods $(0,2,4,6$ e 8 months) under controlled temperature (TC) and room temperature (RT) conditions in the warehouse, at Alto Garças - State of Mato Grosso, Cultivar (C), Enviroment (E) e Storage (S).

\begin{tabular}{|c|c|c|c|c|c|c|}
\hline \multirow{2}{*}{$\mathrm{FV}$} & \multirow{2}{*}{ GL } & \multicolumn{5}{|c|}{ Average Squares } \\
\hline & & $\mathrm{G}$ & $\mathrm{AA}$ & EM & $\mathrm{EC}$ & $\mathrm{CT}$ \\
\hline (C) & 5 & $260.926^{*}$ & $61.816^{*}$ & $148.83 *$ & $428.437 *$ & $906.88 *$ \\
\hline (E) & 1 & $4150.016^{*}$ & $26924.016^{*}$ & $10322.816^{*}$ & $28226.639 *$ & $22233.75^{*}$ \\
\hline$(\mathrm{S})$ & 4 & $3046.691 *$ & $21422.028 *$ & $7736.483 *$ & $38395.235^{*}$ & $22282.860 *$ \\
\hline $\mathrm{C}^{*} \mathrm{E}$ & 5 & $47.766^{*}$ & 9.146 & $112.136^{*}$ & $76.691 *$ & 6.1 \\
\hline $\mathrm{C} * \mathrm{~S}$ & 20 & $22.251 *$ & $23.325^{*}$ & $45.563 *$ & $86.471 *$ & $156.977^{*}$ \\
\hline$E^{*} \mathrm{~S}$ & 4 & $3757.058 *$ & $20599.183^{*}$ & $8099.65^{*}$ & $15534.809 *$ & $15054.656^{*}$ \\
\hline $\mathrm{C}^{*} \mathrm{E}^{*} \mathrm{~S}$ & 20 & 8.958 & $13.463^{*}$ & $44.47 *$ & $103.128 *$ & $5.3187 *$ \\
\hline Residue & 180 & 10.891 & 7.452 & 70.722 & $27.779 *$ & 17.433 \\
\hline $\mathrm{CV}(\%)$ & & 3.58 & 3.2 & 2.91 & 6.32 & 5.13 \\
\hline Average & & 92 & 85 & 91 & 83 & 81 \\
\hline
\end{tabular}

*Significant by $\mathrm{F}$ test at $5 \%$ probability $(\mathrm{p}<0,05)$. 
For accelerated aging test (Figure 1RT), soybean seeds stored under ambient conditions in the warehouse at Alto Garças - MT, Brazil, began the deterioration process after two months, although vigor remained above $80 \%$ until the sixth month. However, there was no further germination at eight months under these conditions and all seeds from all cultivars were dead. Cunha et al. (2009) studied the storage of soybean seeds under ambient conditions and observed a reduction in vigor after six months. In contrast, Carvalho et al. (2014) verified that seeds showed low vigor after eight months of storage under ambient conditions, with values close to zero.

For seeds stored in conventional warehouse Mato Grosso, the behavior was similar for all cultivars (Figure 1RT) whose adjusted model was the second degree, with marked reduction during storage, however the cultivar TMG 115 was that obtained a higher determination coefficient in relation to the others with $93.73 \%$.

It was also verified that under controlled temperature conditions (Figure 1TC), physiological quality was maintained up to eight months, with vigor values still high, with no differences among cultivars. According to Forti et al. (2010), when analyzed soybean seeds stored under different conditions, the environment with controlled temperature provided lower reduction in the physiological quality of seeds throughout the storage.

Regarding the results for accelerated aging (Figure 1TC), for seeds stored in cold chamber there was significant effect only for cultivar TMG 133, whose model was adjusted to the third degree, with a determination coefficient of 79.95, it is observed that This cultivar maintained high vigor until eight months of storage.

Whereas, for seeds stored under ambient conditions in the warehouse at Alto Garças (Figure 1RT), there was a tendency of similar behavior among cultivars and a small decrease in vigor until the fourth month of storage, though, at eighth month these results were significantly reduced. Piccinin et al. (2013), studied soybean cultivars treated with fipronil insecticide for a storage period of 180 days and obtained results significantly lower than the untreated ones. A similar result was found by Pereira et al. (2007) using thiram + thiabendazole in soybean seeds.

Based on electrical conductivity values (Figure 2TC), TMG115, TMG1176, and TMG1179 cultivars stored under controlled temperature conditions and cultivars TMG132 and TMG1179 stored at room temperature in the warehouse at Alto Garças showed better vigor in relation to the others. 

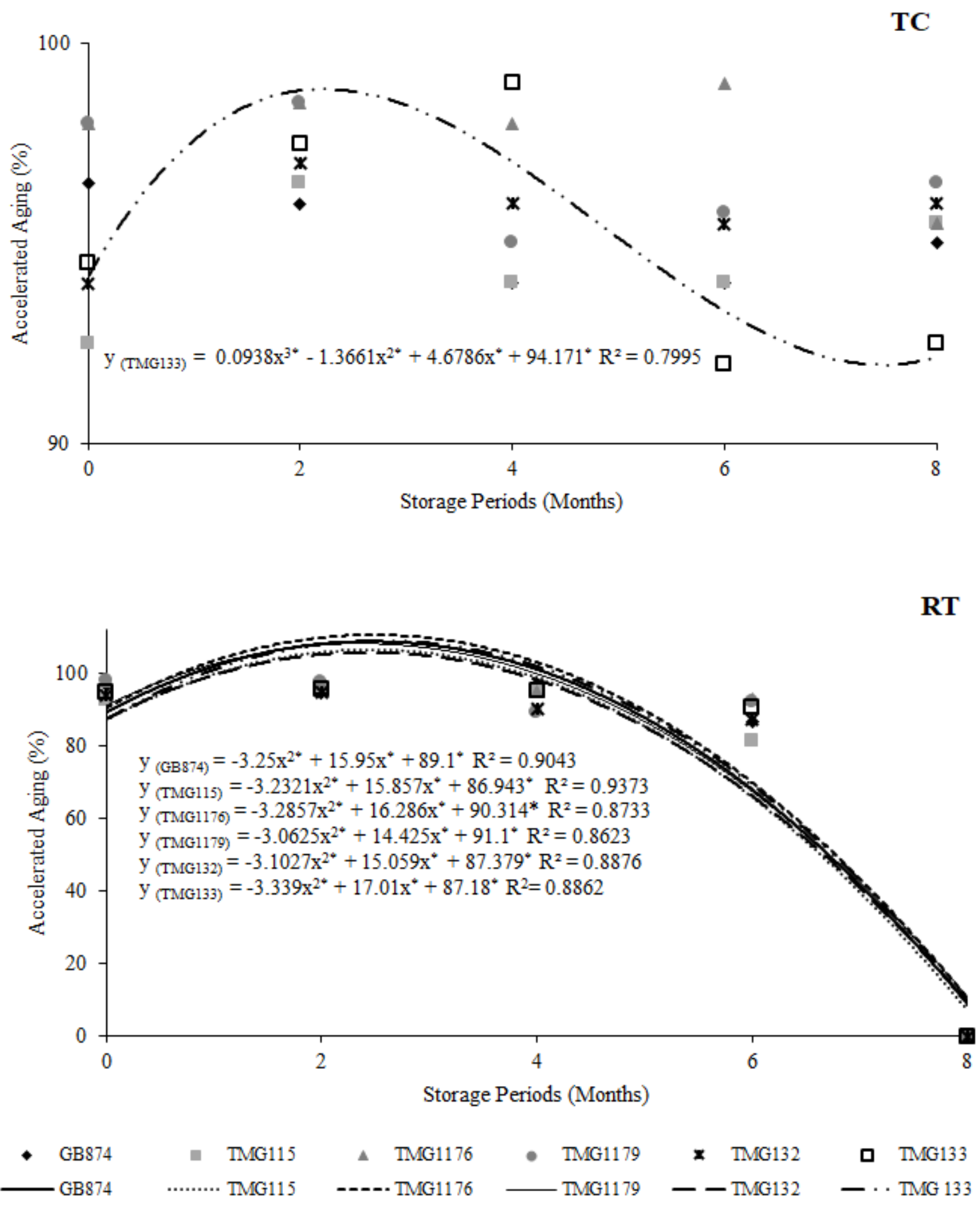

Figure 1. Regression equations for germination (\%) values after accelerated aging of seeds from different soybean cultivars stored according to five storage periods under controlled temperature (TC) and room temperature (RT) conditions in the warehouse, at Alto Garças - State of Mato Grosso, Brazil. 
Still regarding room temperature conditions in the warehouse at Alto Garças (Figure 2RT), high electrical conductivity values at eight months of storage were observed, suggesting greater damage in the membrane system, which reflected directly on the seed quality. This was confirmed with a higher tendency to increase leachate, which shows that conventional storage provides greater and faster seed deterioration.

Carvalho (2009) observed that reduced electrical conductivity values corresponded to higher levels of seed germination and vigor, where reductions in the electrical conductivity values corresponded to lower leaching of solutes and therefore better physiological quality of seeds. Zuchi et al. (2013) observed that cooled seeds had lower leaching of solutes, indicating a better organization of the membrane system. In this sense, it can be affirmed that the studied cultivars with lower electrical conductivity values showed better membrane integrity and hence better physiological quality, which was also confirmed in cold test. However, divergent results were found in accelerated aging and germination tests.

The highest electrical conductivity values in the last storage periods mainly at eight months are related to the reduction in seed vigor, in agreement with the evidence that the seed deterioration process is related to the loss of vigor and changes in the seed integrity of the cell membranes through increase of leaching of organic and inorganic cell constituents (SMANIOTTO et al., 2014).

The results of electrical conductivity obtained for seeds stored at controlled temperature (Figure 2TC) showed low variations, however, the cultivar TMG115 showed linear trend in relation to the other cultivars during storage.

The adjusted model was of the first degree and for the other cultivars, the model was of the second degree. It was observed that three cultivars presented determination coefficient below $90 \%$ in relation to the others. From the behavior of cultivars it was observed that seed treatment did not affect the rate of deterioration during storage, regardless of the conditions under which the seeds were stored.

For the storage room temperature conditions at Alto Garças (Figure 2RT), the values obtained for seeds of all cultivars showed the same tendency of behavior from the initial period to the end of storage. 

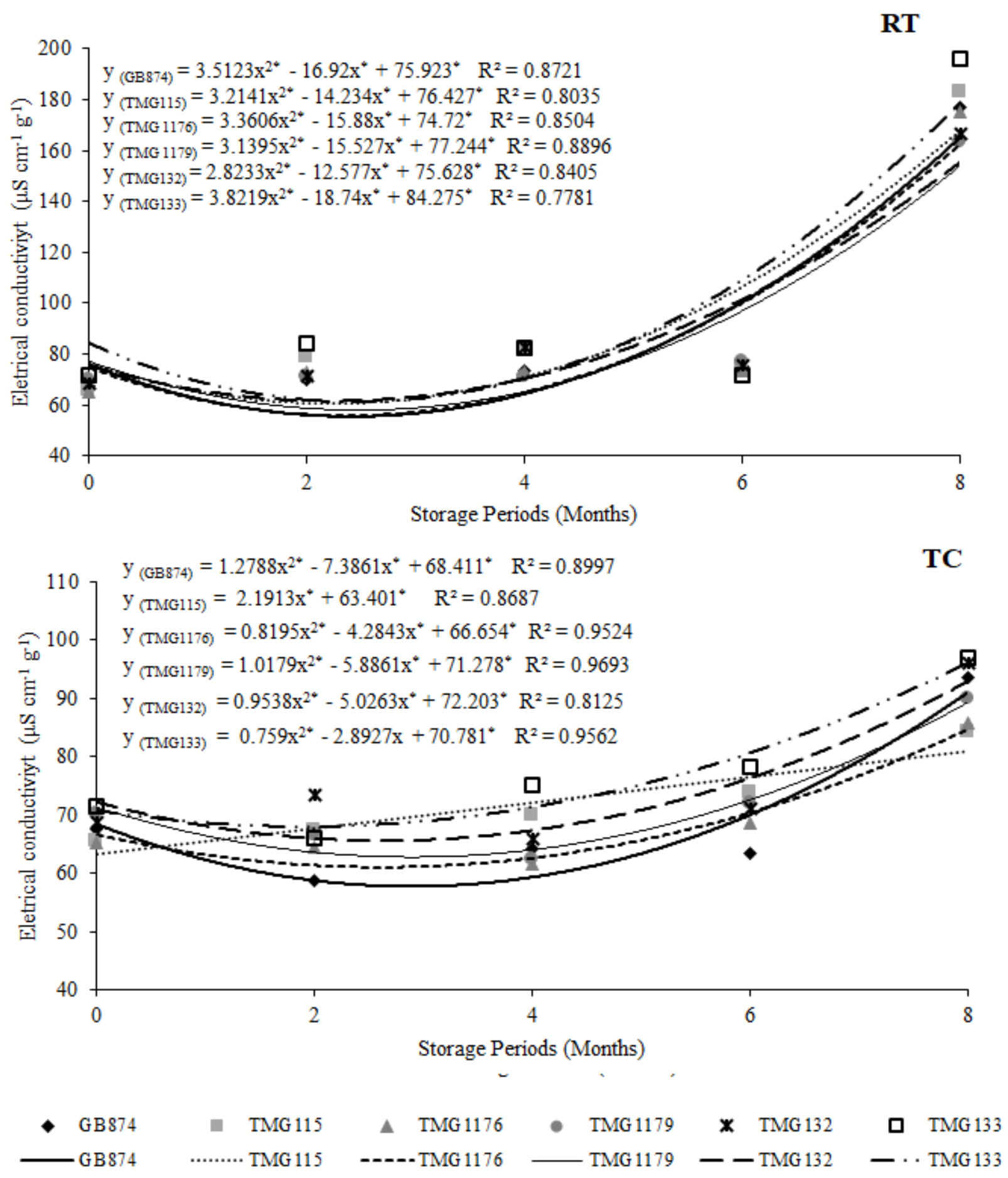

Figure 2. Regression equations for electrical conductivity $\left(\mu \mathrm{S}_{\mathrm{cm}} \mathrm{cm}^{-1} \cdot \mathrm{g}^{-1}\right)$ values of seeds from different soybean cultivars stored according to five storage periods under controlled temperature (TC) and room temperature (RT) conditions in warehouse, at Alto Garças - State of Mato Grosso, Brazil. 
For the emergence results after the cold test (Figure 3), in general, seeds from cultivars showed a lower percentage of normal seedlings in relation to the germination test (Table 3 ). However, the behavior was similar to the other tests, until the sixth month, regardless of the storage conditions, seeds showed vigor above 80\%, except for the cultivar TMG 1176. Seeds stored at room temperature (Figure 3RT) in the warehouse at eight months of storage showed almost zero vigor whereas seeds of cultivar GB874 showed greater vigor in relation to the others when stored at controlled temperature. In contrast, Pereira et al. (2011) studied soybean seeds treated with fungicide associated to the film coating during storage period observed a significant reduction in the quality of these seeds after the sixth month of storage.

For soybean seeds stored under controlled temperature conditions (Figure 3TC), there was a trend of vigor maintenance throughout the storage for all cultivars, except for cultivars TMG132 and TMG 1179, in which small variations occurred in the second month probably due to the occurrence of field fungus present in seeds.

For seeds (Figure 3TC), stored in cold room, seedling emergence after cold test was not significant regression only for cultivar GB874, and for cultivar TMG 132 the adjusted model was the third degree with coefficient. $94.2 \%$, and for the other cultivars, the high school model was adjusted.

At room temperature conditions at Alto Garças (Figure 3RT), there was a similar behavior among cultivars from the beginning to the fourth month of storage, maintaining the vigor above $80 \%$. However, after the fourth month there was a tendency to reduce seed vigor, reaching values close to zero after eight months of storage. Similar results were obtained by Carvalho et al. (2014) determining the physiological and isoenzymatic changes in soybean genotypes under different storage conditions.

According to the graph (Figure 3RT) concerning the regression results of the seed cold test data of the different cultivars stored under ambient conditions in Mato Grosso, analyzed during storage, it is noted that the model that best fit for All cultivars, were the second grade, and the highest coefficient of variation was observed for the cultivar TMG1176, 94.29\%. 

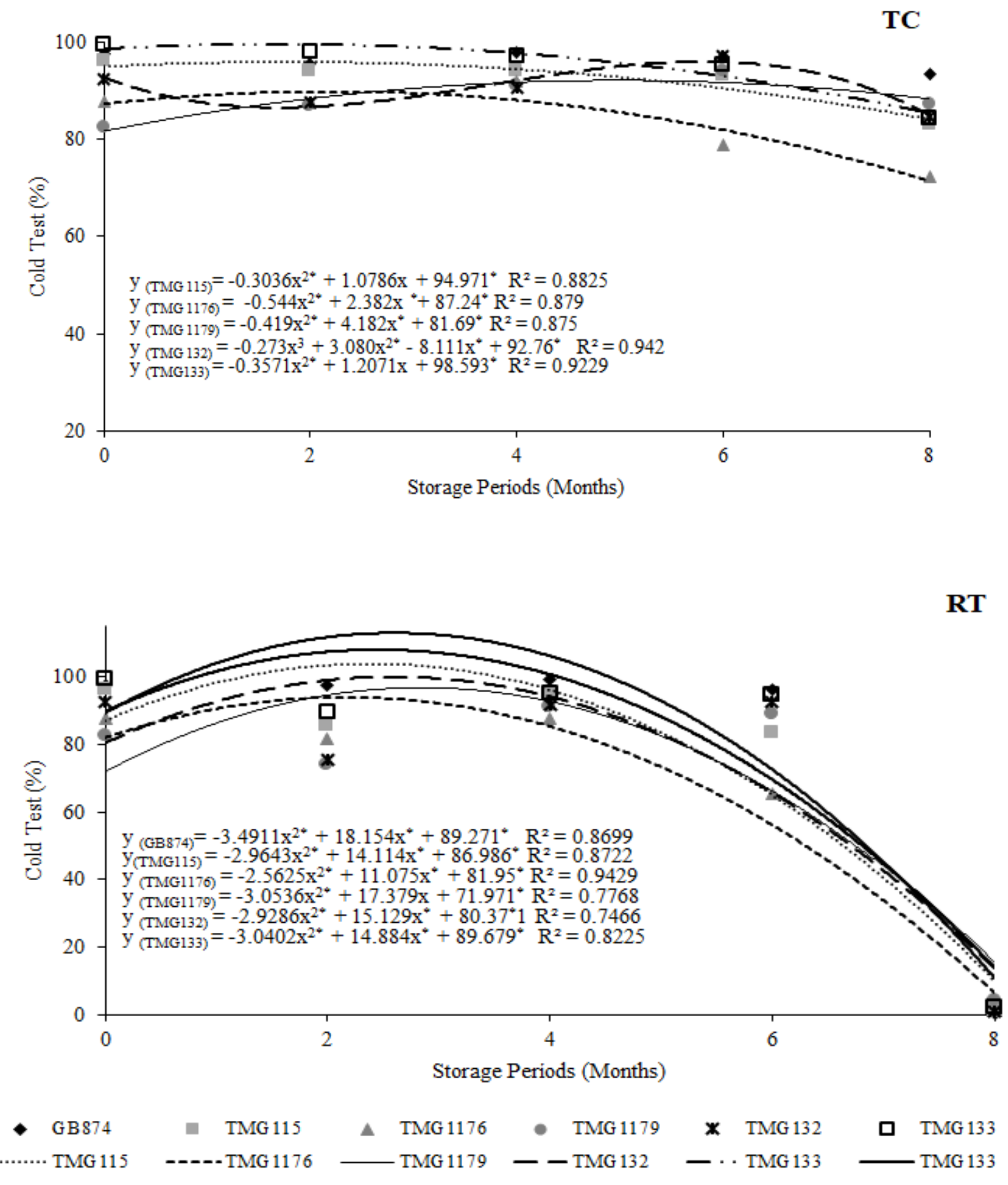

Figure 3. Regression equations for emergence (\%) after cold test of seeds from different soybean cultivars stored according to five storage periods under controlled temperature (A) and room temperature (B) conditions in warehouse, at Alto Garças - State of Mato Grosso, Brazil. 
The emergence test (Table 2) results showed similar behavior to the germination test (Table 3). For storage under controlled temperature conditions, seeds showed emergence percentage above $80 \%$, which did not occur for seeds stored at room temperature in the warehouse after eight months at Alto Garças.

Table 2. Emergence (\%) in seeds from different soybean cultivars stored according to five storage periods under controlled temperature (TC) and room temperature (RT) conditions in the warehouse, at Alto Garças - State of Mato Grosso, Brazil.

\begin{tabular}{|c|c|c|c|c|c|c|c|c|c|c|}
\hline \multirow{3}{*}{ Cultivar } & \multicolumn{10}{|c|}{ Storage Periods (months) } \\
\hline & \multicolumn{2}{|c|}{0} & \multicolumn{2}{|c|}{2} & \multicolumn{2}{|c|}{4} & \multicolumn{2}{|c|}{6} & \multicolumn{2}{|c|}{8} \\
\hline & $\mathrm{TC}$ & TA & $\mathrm{TC}$ & TA & $\mathrm{TC}$ & TA & $\mathrm{TC}$ & TA & $\mathrm{TC}$ & TA \\
\hline TMG 115 & 99 Aa & $99 \mathrm{Aa}$ & $100 \mathrm{Aa}$ & $97 \mathrm{Aa}$ & $96 \mathrm{Ab}$ & $97 \mathrm{Aa}$ & 99 Aa & $90 \mathrm{Bb}$ & $99 \mathrm{Aa}$ & $30 \mathrm{Bd}$ \\
\hline TMG 132 & $98 \mathrm{Aa}$ & $98 \mathrm{Aa}$ & $99 \mathrm{Aa}$ & $98 \mathrm{Aa}$ & $97 \mathrm{Ab}$ & $97 \mathrm{Aa}$ & 96 Аа & $92 \mathrm{Bb}$ & $96 \mathrm{Aa}$ & $40 \mathrm{Bc}$ \\
\hline TMG 1176 & $98 \mathrm{Aa}$ & $98 \mathrm{Aa}$ & $98 \mathrm{Aa}$ & $96 \mathrm{Aa}$ & $96 \mathrm{Ab}$ & $94 \mathrm{Aa}$ & $96 \mathrm{Aa}$ & $85 \mathrm{Bc}$ & $100 \mathrm{Aa}$ & $26 \mathrm{Be}$ \\
\hline TMG 1179 & $98 \mathrm{Aa}$ & $98 \mathrm{Aa}$ & $94 \mathrm{Ab}$ & $95 \mathrm{Aa}$ & $94 \mathrm{Ab}$ & $96 \mathrm{Aa}$ & 96 Аа & $98 \mathrm{Aa}$ & $98 \mathrm{Aa}$ & $48 \mathrm{Bb}$ \\
\hline GB 874 & $100 \mathrm{Aa}$ & $100 \mathrm{Aa}$ & $100 \mathrm{Aa}$ & $98 \mathrm{Aa}$ & 99 Aa & $97 \mathrm{Aa}$ & $99 \mathrm{Aa}$ & 99 Aa & $99 \mathrm{Aa}$ & $53 \mathrm{Ba}$ \\
\hline TMG 133 & $100 \mathrm{Aa}$ & $100 \mathrm{Aa}$ & $100 \mathrm{Aa}$ & $98 \mathrm{Aa}$ & $100 \mathrm{Aa}$ & $98 \mathrm{Aa}$ & $100 \mathrm{Aa}$ & $96 \mathrm{Ba}$ & $99 \mathrm{Aa}$ & $38 \mathrm{Bc}$ \\
\hline
\end{tabular}

Means followed by the same lowercase letter on the columns and uppercase letter on the rows at each storage period do not differ from each other by Scott-Knott test at 5\%.

Thus, at emergence (Table 2), only cultivar TMG 1176 at six months stored under not controlled conditions in Mato Grosso had vigor reduction, demonstrating that until the end of the experiment it was remarkable the process of deterioration of this cultivar thus occurring the reduction in seed quality during seed quality assessment.

In addition, it was observed that the cultivar GB874 at eight months of storage presented greater emergence under ambient conditions than the other cultivars.

For the different soybean cultivars, there was no difference in the emergence of seedlings during the seed storage, showing a good performance when stored under controlled conditions of temperature and RH. Zuchi et al. (2013) evaluated the quality of soybean seeds throughout the storage and verified better performance of seeds cooled during storage. Under room temperatures in the warehouse at Alto Garças, it was verified a small reduction in the seed quality up to fourth month of storage. From this period, the process of deterioration was greater, being significantly increased in the eighth month. 
It was observed a quadratic behavior for germination percentage $(\% \mathrm{G})$ in the seeds from cultivars according to the storage period (Figure 4A), with small variations up to six months of storage and a significant drop after this period. For storage periods and environments, the germination of seeds stored at controlled temperature did not differ along the storage, with average of $96 \%$. However, those stored at room temperature, the effect was quadratic with a drop after the fourth month and mainly after six months of storage under these conditions (Figure 4B). Similar results were obtained by Vieira et al. (2013), which verified that the physiological quality in untreated soybean seeds was maintained when stored at $10^{\circ} \mathrm{C}$ for 12 months, but there was a reduction when stored at $25^{\circ} \mathrm{C}$. In contrast, Juvino et al. (2014) also studied the storage of soybean seeds in an air-conditioned chamber and verified that seeds showed better conservation compared to the natural environment. Demito and Afonso (2009) observed degradation and loss of physiological quality when soybean seeds are stored at room temperature in conventional warehouses. Cunha et al. (2009) observed higher seed deterioration intensity as higher the storage period.

From the results of (Figure 4B), regarding the seed storage conditions, there was significant effect only for the storage results under ambient conditions in Alto Garças - MT, and the best fit model was of the second degree with coefficient of determination. $85.45 \%$.

According to the results (Figure 4A), it is observed that the six cultivars had the same behavior from the zero time until the end of the storage period (eight months), and that the cultivar TMG 1176 had the largest reduction over the period. storage.

Soybean seeds stored at controlled temperature kept the germination percentage above those stored under ambient condition for all cultivars (Table 3).

Percentages were above $80 \%$ in both environments, which is the minimum standard of commercialization required for soybean cultivation established by Normative Instruction $\mathrm{N}^{\circ} .45$ (MAPA, 2013). Thus, seed treatment with imidacloprid + thiodicarb insecticide combined with carboxin + thiram fungicide did not cause a phytotoxic effect on seeds during the studied storage period. Juvino et al. (2014) also studied soybean seeds and observed high values of germination and vigor during nine months of storage. 

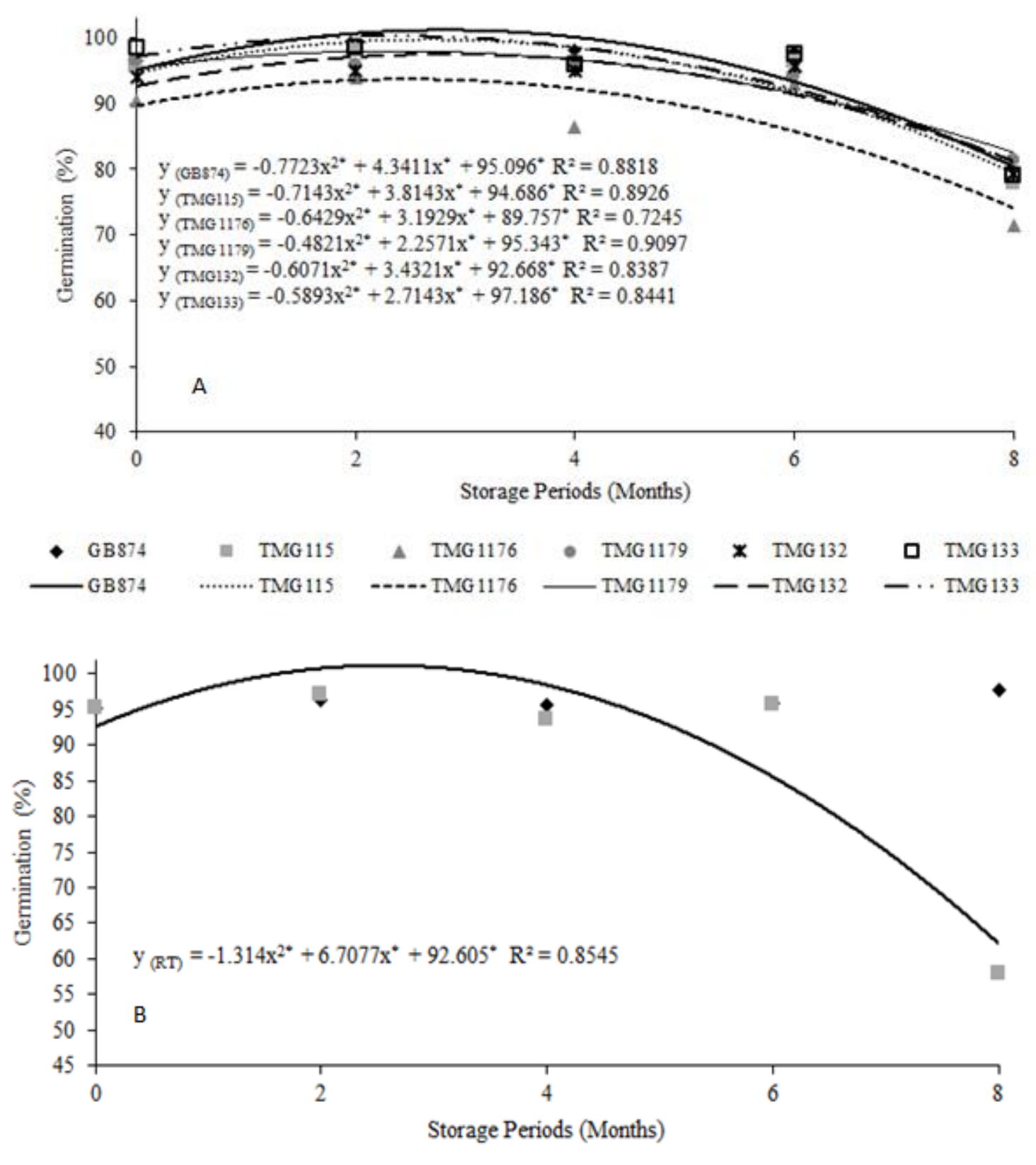

- Controlled Temperature (TC) $\quad$ noom Temperature $(\mathrm{RT}) \quad$ RT

Figure 4. Regression equations for germination (\%) of seeds from different soybean cultivars stored according to five storage periods under controlled temperature (TC) and room temperature (RT) conditions in warehouse, at Alto Garças - State of Mato Grosso Brazil. 
Table 3. Seed germination (\%) from different soybean cultivars stored under controlled temperature (TC) and room temperature (RT) conditions in warehouse, at Alto Garças State of Mato Grosso Brazil.

\begin{tabular}{ccccccc}
\hline \multirow{2}{*}{ Environment } & \multicolumn{6}{c}{ Cultivar } \\
\cline { 2 - 7 } & TMG 1176 & TMG1179 & TMG 132 & TMG 133 & TMG 115 & GB 874 \\
\hline TC & $93 \mathrm{Ba}$ & $96 \mathrm{Aa}$ & $95 \mathrm{Aa}$ & $98 \mathrm{Aa}$ & $98 \mathrm{Aa}$ & $98 \mathrm{Aa}$ \\
TA & $81 \mathrm{Bb}$ & $89 \mathrm{Ab}$ & $89 \mathrm{Ab}$ & $90 \mathrm{Ab}$ & $88 \mathrm{Ab}$ & $90 \mathrm{Ab}$ \\
\hline
\end{tabular}

Means followed by the same lowercase letter on the columns and uppercase letter on the rows at each storage period do not differ from each other by Scott-Knott test at 5\%.

Regarding the germination results presented in (Table 3), that the seeds treated and stored in the cold chamber presented higher percentages in relation to the storage under not controlled conditions in Mato Grosso, regardless of the cultivar.

\section{CONCLUSION}

Seeds from soybean cultivars treated with insecticide (imidacloprid + thiodicarb) and fungicide (carboxin + thiram) stored under controlled temperature and relative humidity conditions kept their physiological quality during eight months of storage.

In the warehouse under room temperatures at Alto Garças, MT, Brazil, the deterioration rate of seeds treated with insecticide (imidacloprid + thiodicarb) and fungicide (carboxin + thiram) is accentuated after six months of storage.

\section{REFERENCES}

BALARDIN, R. S.; SILVA, F. D. L.; DEBONA, D.; CORTE, G. D.; FAVERA, D. D.; TORMEN, N. R. 2011. Tratamento de sementes com fungicidas e inseticidas como redutores dos efeitos do estresse hídrico em plantas de soja. Ciência Rural, Santa Maria, v.41, n.7, p.1120-1126.

BRASIL. 2009, Ministério da Agricultura, Pecuária e Abastecimento - MAPA. Secretaria de Defesa Agropecuária. Regras para análise de sementes. Brasília: Mapa/ACS, 399p.

BRZEZINSKI, C. R.; HENNING, A. A.; ABATI, J.; HENNING, F. A.; FRANÇA-NETO, J. B.; KRZYZANOWSKI, F. C.; ZUCARELI, C. 2015. Seeds treatment times in the establishment and yield performance of soybean crops. Journal of Seed Science, Londrina, v.37, n.2, p.147153.

CARVALHO, L. F. 2009. Influência da temperatura de embebição da semente de soja no teste de condutividade elétrica para avaliação da qualidade fisiológica. Revista Brasileira de Sementes, Londrina, v.31, n.1, p.009-017.

CARVALHO, E. R.; MAVAIEIE, D. P. R.; OLIVEIRA, J. A.; CARVALHO, M. V.; VIEIRA, A. R. 2014. Alterações isoenzimáticas em sementes de cultivares de soja em diferentes condições de armazenamento. Pesquisa Agropecuária Brasileira, Brasília, v.49, n.12, p.967-976. 
COMPANHIA NACIONAL DE ABASTECIMENTO. 2019. Acompanhamento da safra brasileira: grãos, décimo segundo levantamento, setembro 2019. Available in: <www.conab.gov.br/info-agro/safras/graos/boletim-da-safra-de-graos_setembro_2019.pdf >.

CUNHA, J. P. A. R.; OLIVEIRA, P.; SANTOS, C. M.; MION, R. L. 2009. Qualidade sementes de soja após a colheita com dois tipos de colhedora e dois períodos de armazenamento. Ciência Rural, Santa Maria, v.39, n.5, p. 1420-1425.

CUNHA, R. P. I; CORRÊA, M. F., SCHUCH, L. O.B; OLIVEIRA, R. C.; JUNIOR, J. S. A.; SILVA, J. D. G.; ALMEIDA, T. L. 2015. Diferentes tratamentos de sementes sobre o desenvolvimento de plantas de soja. Ciência Rural, Santa Maria, v.45, n.10, p.1761 - 1767.

DEMITO, A.; AFONSO, A. D. L. 2009. Qualidade das sementes de soja resfriadas artificialmente. Engenharia na Agricultura, Viçosa, v.17, n.1, p. 7-14.

FERREIRA, D. F. 2014. Sisvar: A guide for its bootstrap procedures in multiple comparisons. Ciência e Agrotecnologia, Lavras, v.38, n.2, p.109-112.

FERREIRA, T. F. OLIVEIRA, J. A, CARVALHO, R. A, RESENDE, L. S. LOPES, C. G. M, FERREIRA, V. F. 2016. Quality of soybean seeds treated with fungicides and insecticides before and after storage. Journal of Seed Science, Londrina, v. 38, n.4, p. 278-286.

FORTI, V. A; CICERO, S. M.; PINTO, T. L. F. 2010. Avaliação da evolução de danos por "umidade" e redução do vigor em sementes de soja, cultivar TMG113-RR, durante o armazenamento, utilizando imagens de raios $\mathrm{X}$ e testes de potencial fisiológico. Revista Brasileira de Sementes, Londrina, v.32, n.3, p.123-133.

JUVINO, A. N. K.; RESENDE, O.; COSTA, L. M.; SALES, J. F. 2014. Vigor da cultivar BMX Potência RR de soja durante o beneficiamento e períodos de armazenamento. Revista Brasileira de Engenharia Agrícola e Ambiental, Campina Grande, v.18, n.8, p.844-850.

MARCOS FILHO, J. 1999. Teste de envelhecimento acelerado. In: KRZYZANOWSKI, F. C.; VIEIRA, R. D.; FRANÇA NETO, J. B. (Ed.). Vigor de sementes: conceitos e testes, Londrina: ABRATES, p.3.24-3.32.

MINISTÉRIO DA AGRICULTURA, PECUÁRIA E ABASTECIMENTO - MAPA. 2013. Instrução Normativa n. 45, de 17 de setembro de 2013. Padrões de identidade e qualidade para produção e comercialização de sementes. Anexo IX - Padrões para produção e comercialização de sementes de soja.

PEREIRA, C. E; OLIVEIRA, J. A; EVANGELISTA, J. R. E; BOTELHO, F. J. E; OLIVEIRA, G. E; TRENTINI, P. 2007. Desempenho de sementes de soja tratadas com fungicidas e peliculizadas durante o armazenamento. Ciência Agrotecnologia, Lavras, v.31, n.3, p.656665.

PEREIRA, C. E.; GUIMARÃES, R. M.; VIEIRA, A. R.; EVANGELISTA, J. R. E.; OLIVEIRA, G. E. 2011. Tratamento fungicida e peliculização de sementes de soja submetidas ao armazenamento. Ciência Agrotecnologia, Lavras, v.35, n.1, p.158-164.

PICCININ, G. G.; BRACCINI, A. L.; DAN, L. G. M.; BAZO, G. L.; LIMA, L. H. S. 2013. Influência do armazenamento na qualidade fisiológica de sementes de soja tratadas com inseticidas. Revista do Setor de Ciências Agrárias e Ambientais, Guarapuava, v.9, n.2, p.289-298.

REGINATO, M. P.; ENSINAS, S. C.; RIZZATO, M. C. O; SANTOS, M. K. K; PRADO, E. A. 2014. BOAS PRÁTICAS DE ARMAZENAGEM DE GRÃOS. ENEPEX. P. 1-19.

SCHONS, A.; SILVA, C. M.; PAVAN, B. E.; SILVA, A. V.; MIELEZRSK, F. 2018. Respostas do genótipo, tratamento de sementes e condições de armazenamento no potencial fisiológico de sementes de soja. Revista de Ciências Agrárias, Lisboa, v. 41, n.1, p. 111-120. 
SMANIOTTO, T. A. S.; RESENDE, O.; MARÇAL, K. A. F.; OLIVEIRA, D. E. C.; SIMON, G. A. 2014. Qualidade fisiológica das sementes de soja armazenadas em diferentes condições. Revista Brasileira de Engenharia Agrícola Ambiental, Campina Grande, v.18, n.4. p.446 453.

TOLEDO, M. Z.; FONSECA, N. R.; CESAR, M. L.; SORATTO, R. P.; CAVARIANI, C.; CRUSCIOL, C. A. C. 2009. Qualidade fisiológica e armazenamento de sementes de feijão em função da aplicação tardia de nitrogênio em cobertura. Pesquisa Agropecuária Tropical, Goiânia, v.39, n.2, p.124-133.

VIEIRA, R. D. 1994. Teste de condutividade elétrica. In: VIEIRA, R.D.; CARVALHO, N.M. (Ed.). Testes de vigor em sementes. Jaboticabal: FUNEP, p.103-132.

VIEIRA, B. G. T. L.; BARBOSA, G. F.; BARBOSA, R. M.; VIEIRA, R.D. 2013. Structural changes in soybean seed coat due to harvest time and storage. Journal of Food, Agriculture and Environment, Helsinki, v.11, n.1, p.625-628.

ZUCHI, J.; FRANÇA NETO, J. B.; SEDIYAMA, C. S.; LACERDA FILHO, A. F.; REIS, M. S. 2013. Physiological quality of dynamically cooled and stored soybean seeds. Journal of Seed Science, Londrina, v.35, n.3, p.353-360.

Received in: December, 8, 2018

Accepted in: December, 5, 2019 